\title{
Intrauterine Hypoxia-Ischemia Increases $N$-Methyl- $D$-Aspartate-Induced cGMP Formation and Glutamate Accumulation in Cultured Rat Cerebellar Granule Cells
}

\author{
ZHENGWEI CAI, TED SIGREST, KELLY HERSEY, AND PHILIP G. RHODES \\ Department of Pediatrics, Division of Newborn Medicine, University of Mississippi Medical Center, \\ Jackson, Mississippi 39216-4505
}

\section{ABSTRACT}

Effects of intrauterine hypoxia-ischemia (HI) on brain functional development in the term rat were examined in cerebellar granule cell cultures obtained from an in utero $\mathrm{HI}$ model. On gestation $\mathrm{d} 17$, HI conditions were achieved by complete clamping of the uterine vasculature for designated durations followed by removal of the clamps to permit reperfusion. Sham operation (surgery without vasculature clamping) was performed as the control. After surgery, the uterine horns were returned to dam's abdomen to let the pups deliver naturally. Severe HI insult from the surgical manipulation was evident in that the lactate levels of fetal brain increased, and fetal blood $\mathrm{pH}$ decreased with the duration of vasculature clamping up to $1 \mathrm{~h}$. The experimental $\mathrm{HI}$ insult up to $1 \mathrm{~h}$ did not affect fetal survival rate, but retarded growth of fetuses or newborns was observed in the $1 \mathrm{~h} \mathrm{HI}$ group. $\mathrm{N}$-Methyl-D-aspartate (NMDA)- and kainate (KA)-stimulated cGMP formation and glutamate accumulation were measured in cerebellar granule cell cultures from 8-d-old pups suffering from various durations of antenatal HI insult. NMDA (100 $\mu \mathrm{M})$ induced elevation of cGMP was further augmented by a $10-35-$ min HI insult as compared with the control cells (62.4-78.2 versus $49 \mathrm{pmol} / \mathrm{mg}$ protein). In the presence of $\mathrm{L}-N^{\mathrm{G}}$ monomethyl-arginine (L-NMMA, $150 \mu \mathrm{M}$ ), a nitric oxide syn- thase inhibitor, NMDA-induced cGMP formation was blocked, and the blockade of cGMP formation by L-NMMA $(10 \mu \mathrm{M})$ could be reversed by simultaneous application of $1 \mathrm{mM}$ arginine in both control and HI cells. Antenatal HI insult (20-35 min) also augmented NMDA-, but not KA-, stimulated accumulation of extracellular glutamate. The hypersensitive response in NMDAinduced glutamate accumulation could be suppressed by $150 \mu \mathrm{M}$ L-NMMA. The overall results suggest that antenatal HI occurring in the last half of gestation may result chronically in adverse effects on NMDA receptor-mediated neurotransmission and that nitric oxide is possibly involved in these effects. (Pediatr Res 38: 107-112, 1995)
HI, hypoxia-ischemia
Abbreviations
EAA, excitatory amino acid
NO, nitric oxide
L-NMMA, L- $N$-monomethyl-arginine
NMDA, $N$-methyl-D-aspartate

KA, kainate

ANOVA, analysis of variance

HEPES, $N$-2-hydroxyethylpiperazine- $N^{\prime}$-2-ethanesulfonic acid
In utero $\mathrm{HI}$ is a major contributor to long-term neurologic abnormalities. The severe sequelae include learning disabilities, motor disturbances, behavioral alterations, and mental retardation $(1,2)$. The establishment of many perinatal $\mathrm{HI}$ animal models $(3,4)$, including several rat models $(5-8)$, has greatly expanded our knowledge of the critical events and biochemical alterations occurring during or after the initial $\mathrm{HI}$ insult. However, in most of these experimental models the HI insult is given acutely near term or during the first a few days of postnatal life (in case of the rat model), which is thought to be a developmental stage equivalent to the third trimester in

Received November 18, 1994; accepted March 7, 1995.

Correspondence: Dr. Philip G. Rhodes, Department of Pediatrics, Newborn Medicine, University of Mississippi Medical Center, 2500 N. State Street, Jackson, MS 39216-4505. humans, and brain injury is determined immediately after the insult. It is not fully understood whether and how HI occurring at a relatively early gestational stage results in chronic adverse effects on CNS development. Recent animal studies have provided evidence that intermittent antenatal hypoxia has longterm effects on rat brain ornithine decarboxylase activity and causes several behavioral changes, although with maturation those abnormal behaviors are not evident (9). Clinical evidence also indicates that neurologic damage in newborn infants due to antenatal insults is demonstrable $(10-12)$ and that the observed neonatal encephalopathy, after the exclusion of infants with major malformations or infections, is not always due to birth asphyxia and is sometimes due to preexisting abnormalities (13). It is thus desirable to have an animal model for 
studying the chronic effects of in utero $\mathrm{HI}$ on postnatal brain development.

Considerable experimental evidence indicates that alteration in glutamate neurotransmission is one of the important factors in the HI-induced brain injury $(1,14-18)$. As a major EAA neurotransmission system, the glutamate receptors can be categorized into two subgroups, metabotropic and ionotropic receptors, which include three subtypes based on selective activation with the agonists: NMDA, KA, and ( \pm )- $\alpha$-amino3-hydroxy-5-methyl-4-isoxazolepropionate. During HI insult, an excessive amount of glutamate is released $(19,20)$ and results in massive influx of ions and water and eventual neuronal cell death (15). In addition to the direct neuronotoxic effects of glutamate, activation of EAA receptor subtypes has been shown to trigger the $\mathrm{Ca}^{2+}$-dependent synthesis of the novel intercellular messenger, NO, from L-arginine $(21,22)$. Inhibition of NO synthesis from $\mathrm{L}$-arginine has been reported to reduce brain injury associated with $\mathrm{HI}$ in mice and immature rats $(23,24)$, suggesting that formation of NO is possibly involved in the brain injury during and after $\mathrm{HI}$ insults. Because a major action of NO so formed is to stimulate the enzyme guanylate cyclase and thus trigger cGMP synthesis, cGMP levels could be taken as an indirect measurement of NO formation (21). The objective of the present study is to examine the chronic effects of in utero $\mathrm{HI}$ occurring at a relatively early gestational stage on the functional changes in the glutamate neurotransmission system.

\section{METHODS}

Chemicals. Unless otherwise stated, all chemicals used in this study were purchased from Sigma Chemical Co. (St. Louis, MO). $\left[{ }^{3} \mathrm{H}\right] \mathrm{cGMP}$ assay kit was obtained from Amersham Corp. (Arlington Heights, IL).

Animal surgery. Pregnant Sprague-Dawley rats (Harlan Industries, Indianapolis, IN) at $17 \mathrm{~d}$ of gestation were used for the in utero $\mathrm{HI}$ surgery. Under anesthesia induced by isoflurane (4\% induction, $1 \%$ maintenance), an abdominal midline incision was performed, and the uterine horns were exposed. The HI conditions were achieved by complete clamping of the uterine vasculature for designated time periods followed by removal of the clamps to permit reperfusion. Sham operation (surgery without vasculature clamping) was conducted in the control groups. After surgery, the uterine horns were returned to the dam's abdomen to let the pups deliver naturally. One day after the pups were delivered, the litter size was culled to nine (in some batches, 10). Cerebella from the pups at $8 \mathrm{~d}$ of age were used for neuronal cell cultures.

For determination of fetal brain lactate levels during HI, only blood vessels leading to one uterine horn were clamped in some surgeries, and the fetuses in the other uterine horn served as the sham-operated group. Immediately after the designated time periods of $\mathrm{HI}$ insult, fetal brains were collected within 10 $\mathrm{s}$ after decapitation and kept on dry ice until the brain lactate levels were measured the same day.

Due to the small size of the fetuses at $17 \mathrm{~d}$ of gestation, it was difficult to collect the fetal blood samples. We conducted the surgery on some rats at $20 \mathrm{~d}$ of gestation. Fetuses were delivered immediately after the HI insult, and blood samples were collected directly from the fetal heart. Fetal blood $\mathrm{pH}$ was measured by a $\mathrm{pH} / \mathrm{blood}$ gas analyzer (Instrumentation Laboratory, Lexington, MA).

Cell culture. Cerebellar granule cells were cultured as described by McCaslin and Ho (25) with minor modifications. Six milliliters of dissociating medium per rat pup cerebellum were used. Cells were grown in Dulbecco's modified Eagle's medium containing $12 \%$ defined/supplemented bovine calf serum (Hyclone, Logan, Utah), $4 \mathrm{mM}$ glutamine, $25 \mathrm{mM}$ glucose in the absence of antibiotics on glass slides coated with poly-L-lysine at $37^{\circ} \mathrm{C}$ under $10 \% \quad \mathrm{CO}_{2} / 90 \%$ room air. Fresh medium containing cytosine arabinoside $(5 \mu \mathrm{M})$ and $\mathrm{KCl}(25$ $\mathrm{mM}$ ) was added $24 \mathrm{~h}$ later. Cells grown $8 \mathrm{~d}$ in vitro were used for the cGMP measurement and 11-15 $\mathrm{d}$ in vitro cells for the glutamate cumulation measurement.

Lactate determination. Fetal brain lactate levels were determined following the methods described by Magal et al. (7) with minor modification. Briefly, brain tissues were homogenized in two volumes of $20 \mathrm{mM}$ potassium phosphate buffer (pH 6.0) containing $0.5 \mathrm{mM}$ DTT, and two volumes of cold perchloric acid (8\%) were added to one volume of the homogenate. The mixtures were centrifuged at $1500 \times \mathrm{g}$ for $10 \mathrm{~min}$, and aliquots of $0.1 \mathrm{~mL}$ of the supernatant were analyzed by the lactic dehydrogenase enzymatic method using a kit from Sigma Chemical Co. in the presence of excessive NAD.

Determination of cGMP accumulation. The culture medium was removed from cells by three washes with a physiologic balanced salt buffer containing the following $\mathrm{mM}$ concentrations: $154 \mathrm{NaCl}, 5.6 \mathrm{KCl}, 2.5 \mathrm{CaCl}_{2}, 10$ glucose, 40 bicarbonate, and 5 HEPES ( $\mathrm{pH} 7.4$; PSH buffer). The cells were placed in $4 \mathrm{~mL}$ of PSH buffer and preincubated at $37^{\circ} \mathrm{C}$ for $20 \mathrm{~min}$ before the addition of agonists. Three minutes after addition of stimulants, the reaction was terminated by aspirating the incubation buffer, and cells were harvested in $0.35 \mathrm{~mL}$ of hot $1 \mathrm{M}$ perchloric acid $\left(100^{\circ} \mathrm{C}\right)$. The cell suspension was sonicated and centrifuged at $4500 \times g$ for $2 \mathrm{~min}$. The supernatant was neutralized with potassium carbonate $(2 \mathrm{M})$ and assayed for cGMP by using the $\left[{ }^{3} \mathrm{H}\right] \mathrm{cGMP}$ assay kit from Amersham. The resulting pellet was dissolved in $0.4 \mathrm{~N} \mathrm{NaOH}$ for measuring cellular protein by the method of Bradford (26).

Accumulation of extracellular glutamate. In determination of glutamate accumulation, cells were washed and preincubated in a similar manner as those used for cGMP determination except that $100 \mathrm{mM}$ sucrose was added to the buffer to prevent EAA agonist-induced cell death. In this way, only the agonist-induced amino acid accumulation, not the release as the result of cell death, was measured (27). After addition of receptor agonists, cells were incubated at $37^{\circ} \mathrm{C}$ for $1 \mathrm{~h}$. Culture buffer was then collected for the determination of amino acids secreted into the buffer, and cells were harvested with $0.35 \mathrm{~mL}$ perchloric acid for protein measurement. Amino acid content was separated and quantified by an HPLC method as described by Ellison et al. (28).

Statistics. Data of measured variables from various HI groups stimulated with the same receptor agonist were subjected to conventional one-way ANOVA. Duncan's multiple comparison was used to determine the significance of differ- 
ences between groups when one-way ANOVA indicated a significant $F$ value. The level of statistical significance was set at $p<0.05$.

\section{RESULTS}

Clamping of uterine vasculature in the present study resulted in a severe HI insult as indicated by the increase of brain lactate levels correlating with the duration of blood flow restriction (Fig. 1a). Although sham operation up to $1 \mathrm{~h}$ also caused a slight increase of fetal brain lactate levels $(0.92-1.51 \mathrm{mg} / \mathrm{g}$ of brain), the lactate levels in $\mathrm{HI}$ fetal brains were significantly higher than the corresponding sham-operated group $5 \mathrm{~min}$ after blood flow restriction $(1.32-2.74 \mathrm{mg} / \mathrm{g}$ of brain). Consistent with the lactate level data, fetal blood $\mathrm{pH}$ in the HI groups was significantly lower than in the sham-operated groups (Fig 1b).

The in utero $\mathrm{HI}$ insult up to $1 \mathrm{~h}$ did not affect fetal survival rate significantly, although the number of stillbirths in the $1 \mathrm{~h}$ $\mathrm{HI}$ group was slightly more than in the other groups. As shown
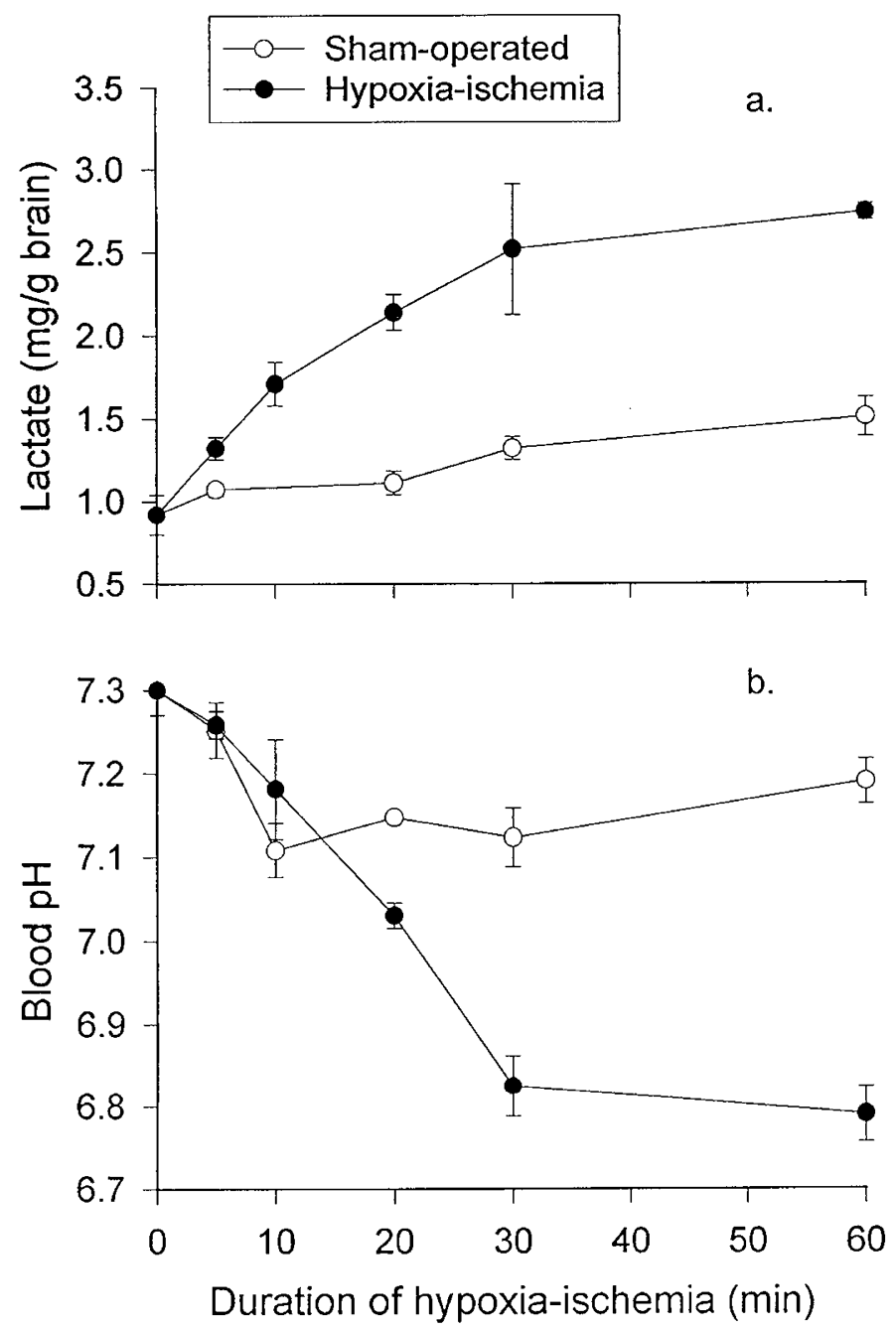

Figure 1. Fetal brain lactate levels $(a)$ and blood $\mathrm{pH}(b)$ during intrauterine HI for various duration. The HI conditions were achieved as described in the footnote of Table 1 and in the text. Only one uterine horn vasculature was clamped for designated time and the other horn served as the sham operation. Each point represents the mean \pm SEM of at least three samples. Data were analyzed by an ANOVA followed by the Duncan's multiple range test. in Table 1, the mean body weight of the pups at $8 \mathrm{~d}$ of age slightly decreased with the increase of HI duration, but the differences in body weight among the sham-operated group and the various HI groups (up to $35 \mathrm{~min}$ ) were not statistically significant. Significantly retarded growth of fetuses or newborns was only observed in the $1 \mathrm{~h} \mathrm{HI}$ group (13.9 versus $16.1 \mathrm{~g}$ ).

The cultural cell densities were not significantly different among intact, sham-operated and up to $35 \mathrm{~min}$ HI groups $(0.5$ $\times 10^{6} /$ slide). Cell cultures from the $1 \mathrm{~h}$ HI group had lower densities $\left(0.3 \times 10^{6} /\right.$ slide $)$, probably due to the small body size. Therefore, only the cultures with similar cell densities were used for cGMP and extracellular glutamate measurements.

The basal level of cGMP in cells cultured from various groups was $7.4 \mathrm{pmol} / \mathrm{mg}$ protein and it was not affected by in utero HI (Fig. 2). Upon the application of NMDA or KA (100 $\mu \mathrm{M}$, each), the cGMP level in cells from the intact group was increased by 7 - and 4-fold, respectively. The NMDA-induced elevation of cGMP was further augmented in HI groups. The NMDA-induced cGMP formation in the 10-35-min HI groups was significantly higher than in the sham-operated group. Antenatal HI for 10-20 min, but not 25-35 min, also augmented the KA-stimulated elevation of cGMP levels.

To further ascertain whether NO formation is involved in the NMDA receptor-mediated cGMP production and the augmentation of cGMP formation by $\mathrm{HI}$, we measured NMDAinduced cGMP in the presence of L-NMMA, a NO synthase inhibitor, in a separate experiment. As shown in Fig. 3, NMDA-induced cGMP formation was inhibited by increasing concentrations of $\mathrm{L}$-NMMA. In the presence of $150 \mu \mathrm{M} \mathrm{L}$ NMMA, NMDA-induced cGMP increase was completely blocked in both control and 25-min HI groups. The blockade of cGMP increase by $10 \mu \mathrm{M}$ L-NMMA was reversed by simultaneous application of $1 \mathrm{mM}$-arginine in both groups. In the presence of L-NMMA, the augmentation of cGMP formation by intrauterine HI disappeared.

The baseline level of extracellular glutamate was low and stable in control and various HI groups as presented in Table 2,

Table 1. Effects of in utero HI on pup's body weight $(g)$ at $8 d$ of

\begin{tabular}{lcc}
\multicolumn{3}{c}{$a g e$} \\
Duration of antenatal & \multicolumn{2}{c}{ Litter size } \\
\cline { 2 - 3 } HI (min) & 9 & 10 \\
\hline Intact & $17.3 \pm 0.3(18)$ & $15.5 \pm 0.6(20)$ \\
Sham-operated & $16.1 \pm 0.3(18)$ & $14.6 \pm 0.2(30)$ \\
5 & $16.9 \pm 0.2(18)$ & $14.5 \pm 1.2(10)$ \\
10 & - & $14.3 \pm 0.5(20)$ \\
20 & $15.0 \pm 0.5(18) \dagger$ & $14.4 \pm 0.5(20)$ \\
25 & - & $14.3 \pm 0.3(20)$ \\
35 & $14.9 \pm 0.4(18) \dagger$ & $13.7 \pm 0.3(30) \dagger$ \\
60 & $13.9 \pm 0.5(27)^{*}$ & - \\
\hline
\end{tabular}

On gestation $\mathrm{d} 17$, intrauterine $\mathrm{HI}$ conditions were achieved by complete clamping of the uterine vasculature for designated time periods followed by removal of the clamps to permit reperfusion. Sham operation (surgery without vaculature clamping) was conducted as the control. The uterine horns were returned to dam's abdomen and pups were born naturally. One day after birth, litter size was culled to nine or 10 . Values are the mean \pm SEM of $(n)$ pups.

${ }^{*} p<0.05$ from the value for the sham-operated group.

$\dagger p<0.05$ from the value for the intact group. 


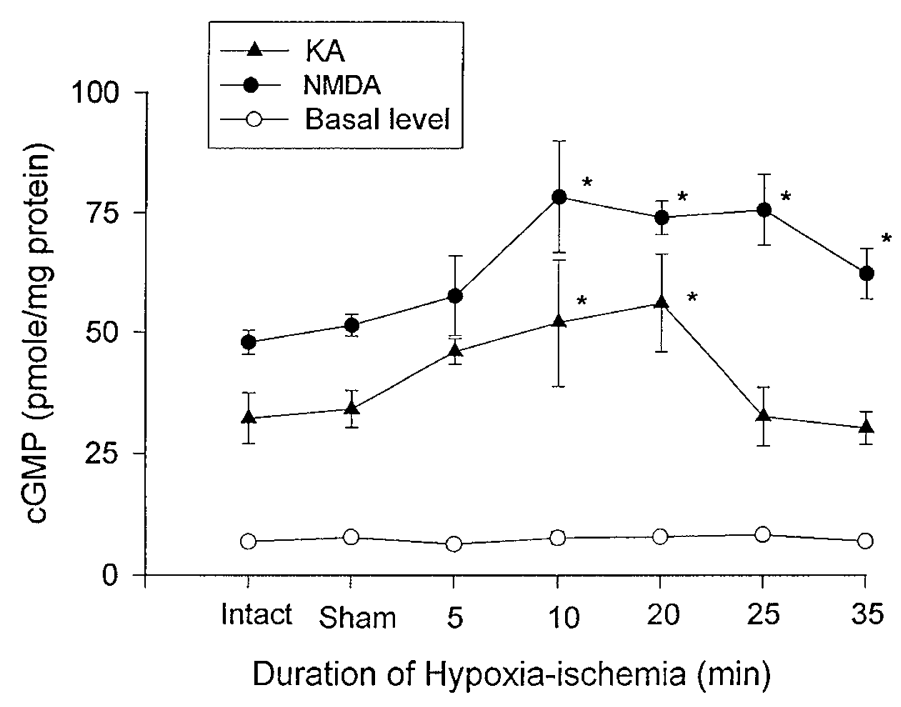

Figure 2. cGMP induced by NMDA or KA (100 $\mu \mathrm{M}$, each) in rat cerebellar granule cell cultures from pups suffered from various durations of intrauterine HI insults. Cells, $8 \mathrm{~d}$ in vitro, were stimulated with NMDA or KA in a physiologically balanced Hepes buffer for $3 \mathrm{~min}$. Each points represents the mean \pm SEM of at least five samples. Data were analyzed by a one-way ANOVA followed by the Duncan's multiple range test. ${ }^{*} p<0.05$ from the value for the sham-operated group stimulated with the same agonist.

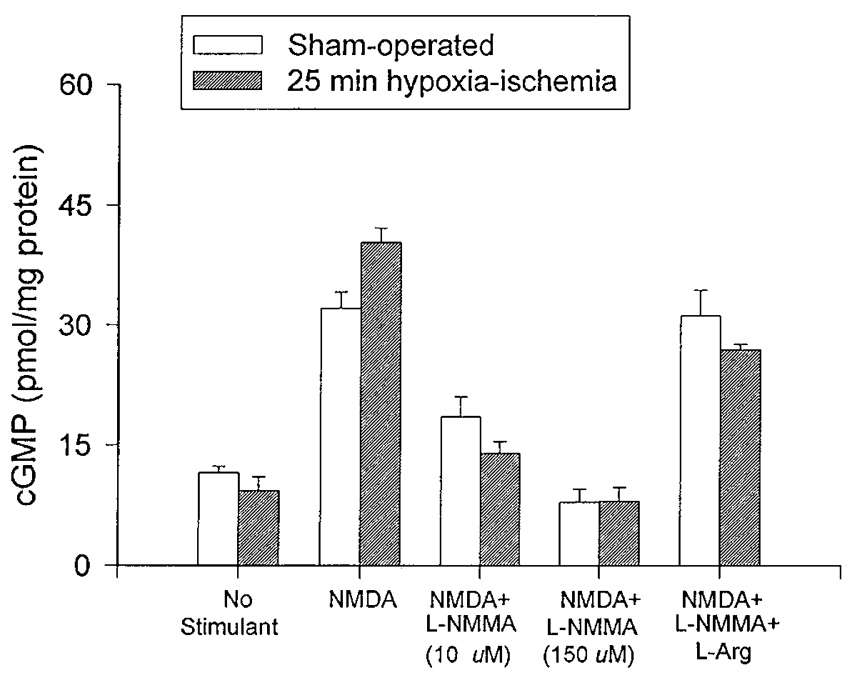

Figure 3. cGMP formation induced by NMDA $(100 \mu \mathrm{M})$ in the presence or absence of L-NMMA and L-arginine ( $\mathrm{L}-\mathrm{Arg}, 1 \mathrm{mM}$ ) in rat cerebellar granule cells cultured from the pups experiencing $25 \mathrm{~min}$ intrauterine $\mathrm{HI}$ or sham operation. Each bar represents the mean \pm SEM of at least five measurements.

apparently through a reuptake mechanism. Stimulation with NMDA or KA (100 $\mu \mathrm{M}$, each) selectively increased glutamate (but not other amino acids) accumulation by 2-3-fold in the sham-operated group. The NMDA-stimulated, but not the KAstimulated, increase in glutamate accumulation was further augmented in the 20 and $35 \mathrm{~min} \mathrm{HI}$ groups by $50-60 \%$. As shown in Fig. 4, simultaneous application of $150 \mu \mathrm{M} \mathrm{L-}$ NMMA reduced NMDA-induced glutamate accumulation in the $35 \mathrm{~min}$ HI group. However, addition of L-NMMA did not affect the KA-induced elevation of glutamate accumulation.

\section{DISCUSSION}

Our major observation in this study is that an in utero $\mathrm{HI}$ insult occurring in the last half of gestation in rats results in an augmentation in NMDA-induced cGMP formation and glutamate accumulation in cultured cerebellar granule cells of the rat progeny. This observation implies that the $\mathrm{HI}$ occurring at an early gestational period may have long-lasting effects on EAA neurotransimission and brain development in perinatal life.

The experimental in utero $\mathrm{HI}$ rat model in the current study is modified from previous models used for studying intrauterine growth retardation $(29,30)$. The current method avoids a long period of severe anoxic conditions for all the fetuses owing to the placental blood vessel ligation as adopted in the previous models and provides a possibility of investigating long-term effects of intrauterine HI during postnatal brain development. The tissue lactic acid level is one of the most widely used parameters to indicate the magnitude of hypoxicischemic insults (31). The time course of brain lactate accumulation in the present study (Fig. 1) is comparable to that reported by Magal et al. (7) in a near term fetal rat ischemia model. It is noticeable that the brain lactate levels in the sham-operated group were also increased with the duration of surgical operation. The increase in lactate levels in shamoperated groups appeared to be due to maternal hypoventilation resulting from anesthesia. Inasmuch as no significant differences in receptor-stimulated cGMP elevation and glutamate accumulation were observed between intact and shamoperated groups, hypoxia resulting from anesthesia contributed little, if any, to the augmentation of NMDA-induced cGMP and glutamate accumulation in HI groups.

Although the role of the activation of glutamate receptors, especially the NMDA receptors, in $\mathrm{HI}$ associated neuron death and brain damage has been extensively studied as one of the important mechanisms $(1,14-18)$, information about the functional changes of the receptor itself after $\mathrm{HI}$ insults is sparse. In a recent study, an increased sensitivity of the NMDA receptor to activation owing to intrauterine hypoxia was reported in fetal guinea pig brain (32). The increased sensitivity of the NMDA receptor to activation was indicated by a greatly enhanced ligand binding affinity and basal activation of NMDA receptor, as well as its increased activation regulated by spermidine (32). As another example of the increased glutamate receptor sensitivity after hypoxic insults, perinatal HI has been found to enhance quisqualate-stimulated phosphoinositide turnover in rat brain slices (33). Consistent with these results, we found in the current study that intrauterine $\mathrm{HI}$ insults caused hypersensitive responses in NMDA-stimulated cGMP formation and glutamate accumulation during the postnatal period. This functional alteration may contribute to the HI brain dysfunction seen in perinatal life. The NMDA receptor has important roles in long-term potentiation and the learning and memory process. Recent studies have provided evidence that NO production inhibits the glutamate receptor, especially the NMDA receptor activation (34-36) by a negative feedback system (35). In the current study, the increased production of $\mathrm{NO}$ in the HI cells, as indicated by the increased formation of NMDA-induced cGMP (Fig. 2), may in turn cause suppression 
Table 2. Extracellular amino acid concentrations (nmole/mg protein)

\begin{tabular}{|c|c|c|c|c|c|}
\hline HI duration & Intact & Sham & $5 \min$ & $20 \mathrm{~min}$ & $35 \mathrm{~min}$ \\
\hline \multicolumn{6}{|l|}{ Glutamate } \\
\hline Basal & $8.8 \pm 0.8$ & $8.0 \pm 1.5$ & $6.4 \pm 0.9$ & $6.5 \pm 1.8$ & $9.7 \pm 0.6$ \\
\hline NMDA-induced & $19.4 \pm 0.9$ & $18.5 \pm 0.7$ & $18.2 \pm 1.3$ & $30.9 \pm 2.8^{*}$ & $27.0 \pm 1.7^{*}$ \\
\hline KA-induced & $25.6 \pm 0.9$ & $25.8 \pm 1.9$ & $19.9 \pm 0.7$ & $26.4 \pm 1.9$ & $25.0 \pm 3.0$ \\
\hline \multicolumn{6}{|l|}{ Alanine } \\
\hline Basal & $51.4 \pm 6.0$ & $57.3 \pm 3.4$ & $51.5 \pm 4.5$ & $64.4 \pm 8.3$ & $54.6 \pm 4.1$ \\
\hline NMDA-induced & $51.7 \pm 4.4$ & $57.5 \pm 6.4$ & $61.9 \pm 4.9$ & $66.0 \pm 8.6$ & $64.3 \pm 7.8$ \\
\hline KA-induced & $57.3 \pm 5.6$ & $49.4 \pm 2.3$ & $47.6 \pm 6.0$ & $57.2 \pm 3.7$ & $54.6 \pm 7.4$ \\
\hline \multicolumn{6}{|l|}{ Glycine } \\
\hline Basal & $34.0 \pm 2.2$ & $40.2 \pm 2.8$ & $35.4 \pm 3.0$ & $42.0 \pm 4.5$ & $33.8 \pm 2.1$ \\
\hline NMDA-induced & $39.2 \pm 1.7$ & $39.5 \pm 2.4$ & $40.1 \pm 3.1$ & $38.8 \pm 5.0$ & $44.6 \pm 2.0$ \\
\hline KA-induced & $33.7 \pm 1.8$ & $39.1 \pm 4.2$ & $46.8 \pm 5.1$ & $42.6 \pm 3.3$ & $35.1 \pm 4.2$ \\
\hline \multicolumn{6}{|l|}{ Histidine } \\
\hline Basal & $7.9 \pm 0.4$ & $9.4 \pm 0.5$ & $8.2 \pm 0.7$ & $10.1 \pm 1.5$ & $8.0 \pm 0.7$ \\
\hline NMDA-induced & $9.1 \pm 0.6$ & $9.1 \pm 0.9$ & $10.4 \pm 0.9$ & $11.5 \pm 0.7$ & $10.5 \pm 0.6$ \\
\hline KA-induced & $7.3 \pm 0.7$ & $9.3 \pm 0.9$ & $9.2 \pm 0.6$ & $9.9 \pm 0.6$ & $8.8 \pm 1.2$ \\
\hline
\end{tabular}

Extracellular amino acid concentrations were determined in cerebellar granule cells cultured from 8 -d-old pups suffering from various durations of intrauterine $\mathrm{HI}$ insults. Cells, 11-15 d in vitro, were stimulated with NMDA or KA, $100 \mu \mathrm{M}$ each, in a physiologically balanced HEPES buffer added with $100 \mathrm{mM}$ sucrose at $37^{\circ} \mathrm{C}$ for $1 \mathrm{~h}$. Amino acid contents were separated and quantified by HPLC. Values are mean \pm SEM of at least five measurements. Data were analyzed by a one-way ANOVA followed by Duncan's test.

$* p<0.05$ from the value for the sham-operated group stimulated with the same agonist.

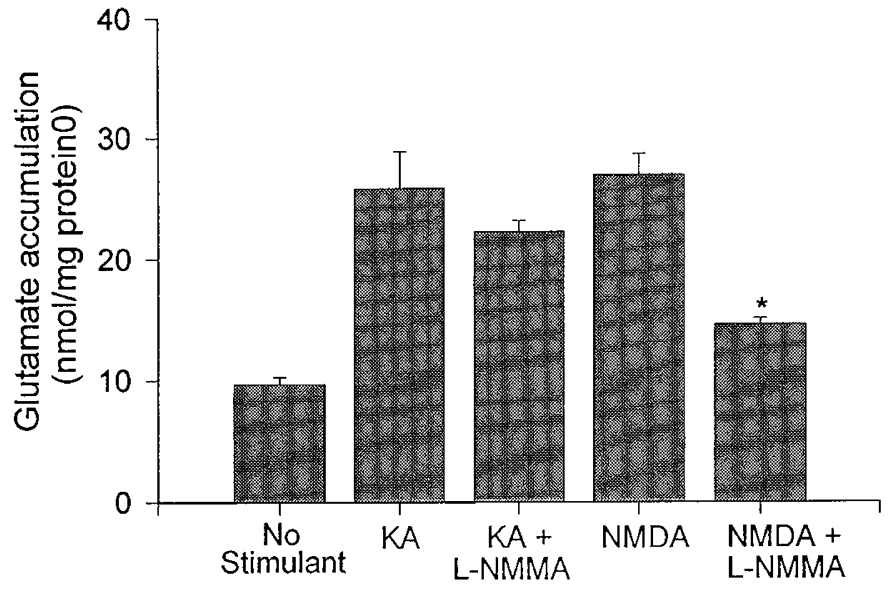

Figure 4. Extracellular glutamate accumulation induced by NMDA or KA (100 $\mu \mathrm{M}$ each) in the presence or absence of L-NMMA $(150 \mu \mathrm{M})$ in rat cerebellar granule cells cultured from the pups suffering from $35 \mathrm{~min}$ of intrauterine HI insult. Experiments were performed as described in the footnote of Table 2 and in the text. Each bar represents the mean \pm SEM of at least five measurements. ${ }^{*} p<0.05$ from the glutamate accumulation stimulated with NMDA alone by a $t$ test.

of NMDA receptor-mediated neurotransmission and affect the learning and memory process. NO production has also been found to enhance NMDA receptor-mediated release of glutamate in guinea pig cerebral cortex (37). This finding is supportive to our observations that the NMDA-induced glutamate accumulation in HI cells was 50\% higher than in shamoperated cells. The augmentation of NMDA-induced glutamate accumulation in $\mathrm{HI}$ cells can be attributed to the increase in NO production, as indicated by the cGMP formation, although blockade of uptake mechanism may also cause increase in extracellular glutamate accumulation, as done by KA (38). In the current study, NMDA- and KA-induced glutamate accumulation seems to occur by different mechanisms, because HI insults only augmented NMDA-induced glutamate accumulation and L-NMMA could block NMDA-induced but not KA- induced glutamate increases. Nevertheless, because excessive glutamate is neurotoxic (14-16), the increased accumulation of NMDA-induced glutamate in HI groups may make the brain more vulnerable to glutamate neurotoxicity in EAA neurotransmission.

The mechanism underlying the hypersensitive responses in cGMP formation and glutamate accumulation upon NMDA receptor activation in antenatal hypoxic-ischemic cells is unclear at present time. Although reduced NMDA receptor number and $\left[{ }^{3} \mathrm{H}\right]$ glutamate binding site measured immediately or $24 \mathrm{~h}$ after $\mathrm{HI}$ insults have been reported in fetal guinea pig brain (32) and neonatal rat brain (39), the availability of an increased number or higher affinity of NMDA receptors in the antenatal hypoxic-ischemic cells remains one of the possible mechanisms. The chronic changes after intrauterine HI insults may differ from the responses measured right after the insults. This possibility is currently under investigation in our laboratory by using the specific radioactive receptor binding ligand. Another question regarding our results is raised. It is known that in the rat cerebellum, neuronal synaptosomal clefts and EAA receptors develop postnatally (40). In the present study, the intrauterine $\mathrm{HI}$ insults occurred on gestation $\mathrm{d} 17$, when the external germinal layer from which the granule cells derive just begins to develop (41). How do the antenatal insults affect postnatal brain receptor functional development? Perinatal HI brain injury has been found to stimulate glial fibrillary acidic protein mRNA and protein expresssion in neonatal rats (42). The investigators found that the increased glial fibrillary acidic protein mRNA was not detected in lesioned hippocampus and striatum until postnatal d 12, whereas the hypoxic-ischemic injury occurred on postnatal $\mathrm{d} 7$. It is possible that the longlasting effect of intrauterine $\mathrm{HI}$ on neurons placed in cultures are mediated by modifying the gene expression for NMDA receptor subunits that have been reported to be altered after forebrain ischemia in adult rats (43). To test this possibility, further investigations are obviously needed and are planned. 
In summary, intrauterine HI enhances NMDA receptorstimulated cGMP formation and glutamate accumulation in rat cerebellar granule cell cultures and NO production may be involved in the altered responses of NMDA receptor activation. This antenatal HI experimental model may be used for studying the chronic effects of intrauterine asphyxia on brain development.

\section{REFERENCES}

1. Vannucci RC 1990 Experimental biology of cerebral hypoxia-ischemia: Relation to perinatal brain damage. Pediatr Res 27:317-326

2. Williams CE, Mallard C, Tan W, Gluckman PD 1993 Pathophysiology of perinatal asphyxia. Clin Perinatol 20:305-325

3. Myers RE 1977 Experimental models of perinatal brain damage: Relevant to human pathology. In: Gluck L (ed) Intrauterine Asphyxia and the Developing Fetal Brain. Year Book Medical Publishers, Chicago, pp 37-97

4. Clapp JG, Li M, Peress NS, Szeto HH 1981 Neuropathology in the chronic fetal lamb preparation: Structure-function correlates under different environmental conditions. Am J Obstet Gynecol 143:973-986

5. Levine S 1960 Anoxic-ischemic encephalopathy in rats. Am J Pathol 36:1-17

6. Johnston MV 1983 Neurotransmitter alterations in a model of perinatal hypoxicischemic brain injury. Ann Neurol 13:511-518

7. Magal E, Goldin E, Harel S, Yavin E 1988 Acute uteroplacental ischemic embryo: Lactic acid accumulation and prostaglandin production in the fetal rat brain. Neurochem 51:75-80

8. Ikonomidou C, Price MT, Mosinger JL, Frierdich G, Labruyere J, Shahid Salles K Olney JW 1989 Hypobaric-ischemic conditions produce glutamate-like cytopathology in infant rat brain. J Neurosci 9:1693-1700

9. Hermans RH, Hunter DE, McGivern RF, Cain CD, Longo LD 1992 Behavioral sequelae in young rats of acute intermittent antenatal hypoxia. Neurotoxicol Teratol 14:119-129

10. Bejar R, Wozniak P, Allard M, Benirschke K, Vaucher Y, Coen R, Berry C, Schragg $P$, Villegas I, Resnik R 1988 Antenatal origin of neurologic damage in newbor infants. Am J Obstet Gynecol 159:357-363

11. Scher MS, Belfar H, Martin J, Painter MJ 1991 Destructive brain lesions of presumed fetal onset: Antepartum causes of cerebral palsy. Pediatrics 88:898-906

12. Shields JR, Schifrin BS 1988 Perinatal antecedents of cerebral palsy. Obstet Gynecol 71:899-905

13. Nelson KB, Leviton A 1991 How much of neonatal encephalophathy is due to birth asphyxia. Am J Dis Child 145:1325-1331

14. Meldrum B 1985 Excitatory amino acids and anoxic-ischemic brain damage. Trends Neurosci 8:47-48

15. Rothman S, Olney J 1986 Glutamate and the pathophysiology of hypoxic-ischemic brain damage. Ann Neurol 19:105-111

16. Choi DW, Rothman SM 1990 The role of glutamate neurotoxicity in hypoxicischemic neuronal death. Annu Rev Neurosci 13:171-182

17. Palmer C, Vannucci RC 1993 Potential new therapies for perinatal cerebral hypoxiaischemia. Clin Perinatol 20:411 423

18. Ikonomidou C. Mosinger JL, Shahid Salles K, Labruyere J, Olney JW 1989 Sensitivity of the developing rat brain to hypobaric/ischemic damage parallels sensitivity to $N$-methyl-aspartate neurotoxicity. J Neuosci 9:2809-2818

19. Andine P, Sandberg M, Bagenholm R, Lehmann A, Hagberg H 1991 Intra- and extracellular changes of amino acids in the cerebral cortex of the neonatal rat during hypoxic-ischemia. Dev Brain Res 64:115-120

20. Silverstein FS, Naik B, Simpson J 1991 Hypoxia-ischemia stimulates hippocampal glutamate efflux in perinatal rat brain: An in vivo microdialysis study. Pediatr Res 30:587-590
21. Garthwaite J 1991 Glutamate, nitric oxide and cell-cell signalling in the nervous system. Trends Neurosci 14:60-67

22. Southam E, East SJ, Garthwaite J 1991 Excitatory amino acid receptors coupled to the nitric oxide/cyclic GMP pathway in rat cerebellum during development. J Neurochem 56:2072-2081

23. Nowicki JP, Duval D, Poignet H 1992 Nitric oxide mediates neuronal death after focal ischemia in the mouse. Eur J Pharmacol 204:339-340

24. Trifiletti RR 1992 Neuroprotective effects of $N^{G}$-nitro-L-arginine in focal stroke in the 7-day-old rat. Eur J Pharmacol 218:197-198

25. McCaslin PP, Ho IK 1994 Cell culture in neurotoxicology. In: Hayes AW (ed) Principles and Methods of Toxicology. Raven Press, New York, pp 1315-1334

26. Bradford MM 1976 A rapid and sensitive method for the quantitation of microgram quantities of protein utilizing the principle of protein-dye binding. Anal Biochem 72:248-254

27. McCaslin PP, Smith TG 1990 Low calcium-induced release of glutamate results in autotoxicity of cerebellar granule cells. Brain Res 417:280-285

28. Ellison DW, Beal MF, Martin JB 1987 Amino acid neurotransmitters in postmotem human brain analyzed by high performance liquid chromatography with electrochemical detection. J Neurosci Methods 19:305-315

29. Wigglesworth JS 1.964 Experimental growth retardation in the fetal rat. J Pathol Bacteriol 88:1-13

30. Goldin E, Harel S, Tomer A, Yavin E 1987 Arachidonic acid oxidation by brain and placenta preparation from normal and placental insufficient fetal rabbit. J Neurochem 48:695-701

31. Myers RE 1979 A unitary theory of causation of anoxic and hypoxic brain pathology. In: Fahn S, Davis JN, Rowland LP (eds) Cerebral Hypoxia and Its Consequences. Raven Press, New York, pp 195-213

32. Mishra OP, Delivoria-Papadopoulos M 1992 NMDA receptor modification in the fetal guinea pig brain during hypoxia. Neurochem Res 17:1211-1216

33. Chen CK, Silverstein FS, Fisher SK, Statman D, Johnson MV 1988 Perinatal hypoxic-ischemic brain injury enhances quisqualic acid-stimulated phosphoinositide turnover. J Neurochem 51:353-359

34. Fujimori H, Pan-Hou H 1991 Effect of nitric oxide on L- $\left[{ }^{3} \mathrm{H}\right]$ glutamate binding to rat brain synaptic membranes. Brain Res 554:355-357

35. Tanaka T, Saito H, Matsuki N 1993 Endogenous nitric oxide inhibits NMDA- and kainate-responses by a negative feedback system in rat hippocampal neurons. Brain Res 631:72-76

36. Kato K, Zorumski CF 1993 Nitric oxide inhibitors facilitate the induction of hippocampal long-term potentiation by modulating NMDA responses. J Neurophysio 70:1260-63

37. Montague PR, Gancayco CD, Winn MJ, Marchase RB, Friedlande MJ 1994 Role of NO production in NMDA receptor-mediated neurotransmitter release in cerebral cortex. Science 263:973-977

38. Pocock JM, Murphie HM, Nicholls DG 1988 Kainic acid inhibits the synaptosoma plasma membrane glutamate carrier and allow glutamate leakage from the cytoplasm but does not affect glutamate exocytosis. J Neurochem 50:745-751

39. Silverstein FS, Torke L, Barks J, Johnston MV 1987 Hypoxia-ischemia produces focal disruption of glutamate receptors in developing brain. Dev Brain Res 34:33-39

40. Altmann $J 1972$ Postnatal development of the cerebellar cortex in the rat. III. Maturation of the components of the granular layer. J Comp Neurol 145:465-513

41. Altman J 1982 Morphological development of the rat cerebellum and some of its mechanisms. Exp Brain Res Suppl 6:8-49

42. Burtrum D, Silverstein FS 1994 Hypoxic-ischemic brain injury stimulates glial fibrillary acidic protein mRNA and protein expression in neonatal rats. Exp Neurol 126:112-118

43. Heurteaux C, Lauritzen I, Widmann C, Lazdunski M 1994 Glutamate-induced overexpression of NMDA messenger RNAs and protein triggered by activation of AMPA/kainate receptors in rat hippocampus following forebrain ischemia. Brain Res 659:67-74 